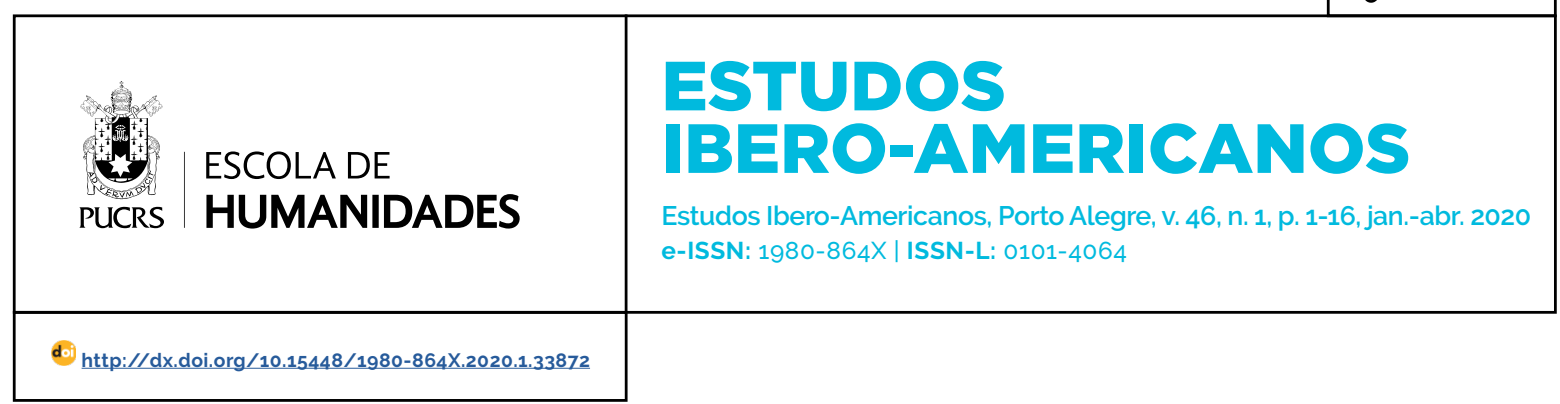

DOSSIÊ

\title{
Um rio, uma cidade: caminhos que se cruzam - São Sebastião do Caí (RS)
}

\author{
A river, a city: crossed paths - São Sebastião do Caí (RS) \\ Un rio, una ciudad: caminos que se cruzan - São Sebastião do Caí (RS)
}

\author{
Magna Lima \\ Magalhães ${ }^{1}$ \\ orcid.org/0000-0001-9661-4178 \\ magna@feevale.br
}

\section{Claudia Schemes ${ }^{1}$ \\ orcid.org/0000-0001-8170-9684 \\ claudias@feevale.br}

\section{Cleber Cristiano \\ Prodanov $^{1}$}

orcid.org/0000-0002-1288-5251 prodanov@feevale.br

Recebido em: 7 mai. 2019. Aprovado em: 30 jul. 2019 Publicado em: 28 abr. 2020
Resumo: Este artigo tem por objetivo apresentar alguns aspectos históricos sobre a cidade de São Sebastião do Caí, situada na região do Vale do Rio Caí, no Estado do Rio Grande do Sul. Intenta-se demonstrar a relação da cidade com o seu rio. Procuramos dentro de uma perspectiva da história cultural urbana e ambiental, entender o rio como um atribuidor de sentidos e significados ao espaço da cidade, bem como um possibilitador de alterações e mudanças sociopolíticas e culturais no cenário local. A metodologia utilizada foi a pesquisa bibliográfica, documental (fotografias e jornais) e história oral. Os resultados mostram que a memória dos moradores está vinculada aos problemas ambientais, em especial, às enchentes que ocorrem no municipio.

Palavras-chave: Rio Caí. Enchente. História urbana. História ambiental. Interdisciplinaridade.

Abstract: This article aims to present some historical aspects of the city of São Sebastião do Cai, located in the region of the Valley of Cai River, in the state of Rio Grande do Sul. Our intent is to demonstrate the city's relationship with its river. We seek within a perspective of urban and environmental cultural history, understand the river as an allocator of senses and meanings to the city space, as well as an enabler of change and socio-political and cultural changes in the local scene. The methodology used was the bibliographical, documentary research, through photographs and newspaper articles, and oral history. The results show that the memory of the residents is linked to environmental problems, especially the floods that occur in the municipality.

Keywords: Cai River. Flood. Urban History. Environmental History. Interdisciplinarity.

Resumen: Este artículo pretende presentar algunos aspectos históricos de la ciudad de São Sebastião do Caí, ubicada en la región del valle del río Caí, en el estado de Rio Grande do Sul. Nuestra intención es demostrar la relación entre la ciudad y su río. Buscamos desde una perspectiva de la historia cultural urbana y ambiental para entender el río como un atributo de significados y significados para el espacio de la ciudad, asi como un facilitador de cambios sociopolíticos y culturales y cambios en el escenario local. La metodología utilizada fue la investigación bibliográfica, documental, a través de fotografias y artículos periodisticos, y la historia oral. Los resultados muestran que la memoria de los residentes está vinculada a problemas ambientales, especialmente las inundaciones que ocurren en el municipio.

Palabras clave: Rio Caí. Inundacion. Historia urbana. Historia ambiental. Interdisciplinariedad.

\section{Introdução}

A proposta deste artigo é refletir sobre a cidade de São Sebastião do Caí, situada na região do Vale do Rio Cai (RS), e sua relação sensivel com o rio que está presente em sua espacialidade. O espaço social, político e físico envolve uma tessitura de práticas que marcam o lugar e engendram relações e construções culturais (DE CERTEAU, 1998).
Artigo está licenciado sob forma de uma licença Creative Commons Atribuição 4.0 Internacional. 
Nesse sentido, ao pensar a construção histórica dessa localidade e a sua relação com o rio principal, não podemos deixar de pensar a partir de uma perspectiva interdisciplinar, em que cultura, cidade, seus personagens e o meio ambiente sejam pensados de forma conjunta e que passam por ressignificações contínuas, emoldurando uma relação revestida de simbolismos, presentes no imaginário local. Desvelar a história local e a sua complexidade perpassa por uma viagem no tempo, no intuito de trazer à luz elementos históricos que nos possibilitem pensar a localidade e a relevância de seu rio. De acordo com a perspectiva da Nova História Urbana, a cidade pode ser pensada por diferentes prismas, como as mudanças espaciais e ecológicas, as relações dos individuos, o trabalho e a familia ou, ainda, a cidade e o processo de urbanização (RAMINELLI, 1997).

Para Barros (2012), a multiplicidade de aspectos que cercam as cidades instiga sociólogos e historiadores a discutirem o fenômeno urbano a partir de diferentes e diversificados indicios. Nessa perspectiva, é possivel perceber a cidade como um "grande texto que tece dentro de si uma miriade de outros textos, inclusive os das pequenas conversas produzidas nos encontros cotidianos" (BARROS, 2012, p. 45). Seus espaços são constituídos por processos urbanos que se sucedem e se inter-relacionam em um tempo que não é linear; a cidade é policrônica (DUARTE, 2006).

Entendemos que a cidade é uma materialidade erigida pelo homem e uma ação humana sobre a natureza. Nesse sentido, corroboramos Pesavento (2007, p. 164), ao discutir o cotidiano na cidade de Porto Alegre e asseverar que "a cidade é vida porque abriga uma população, que habita casas, que anima as ruas, que faz do urbano um espaço de trabalho e lazer, de festa e de dor, de vida e de morte, de crime e de poesia".

Sendo assim, a pesquisa histórica ligada à história ambiental possibilita-nos, conforme Worster (1991, p. 199), uma "ampliação da perspectiva da história de modo a incluir um conjunto mais profundo e diversificado de assuntos", que poderiamos sintetizar como o entendimento da natureza e como ela se organizou e funcionou durante a história; as interações sociais e econômicas com o ambiente - a organização do trabalho a partir dos recursos naturais -; e, por fim, as interações menos concretas que se dão entre indivíduo e natureza, como valores éticos, leis etc. O autor salienta, entretanto, que esses três niveis de estudo ambiental não podem ser tratados isoladamente, mas que "constituem uma investigação única e dinâmica, na qual natureza, organização social e econômica, pensamento e desejo são tratados como um todo" (WORSTER, 1991, p. 202).

De acordo com Pádua (2010), natureza e cultura ou sociedade devem ser analisadas de maneira plural e menos "dualista" ou "mais nuançada": "As visões fechadas e reducionistas não mais se sustentam. Dizer que a natureza sempre determina a vida social, ou vice-versa, não nos leva muito longe" (PÁDUA, 2010, p. 97). Essa concepção vem ao encontro das ideias de Worster (1991) acerca da ampliação da análise histórica, que propõe observar, além das questões da natureza, a economia, a política e a cultura de uma sociedade a partir de uma perspectiva interdisciplinar.

Segundo Worster (1991), normalmente os cientistas não encaram os homens ou as sociedades como partes integrantes dos seus ecossistemas, mas esses é que deveriam ser o principal objeto de estudos dos historiadores. Drummond (1991) acrescenta, nesse sentido, que a história ambiental não se faz em um nivel abstrato, mas a partir de experiências vividas, que podem ser, por exemplo, em uma bacia hidrográfica, objeto de estudo deste trabalho.

A partir das concepções da história ambiental ora discutidas, procuraremos refletir a respeito da percepção que os moradores da cidade de São Sebastião do Caí têm de sua relação com o rio que corta o municipio, pois, segundo Mello (2008, p. 114), "a cidade nasce da água" e a sua história pode ser escrita a partir das dinâmicas hídricas, sendo que "a trajetória das relações entre cidades e corpos d'agua reflete, assim, os ciclos históricos da relação entre homem e natureza". Além disso, "a história ambiental nos ajuda a entender, por um lado, a relação entre os valores culturais, as experiências individuais e as decisões humanas e, por outro, as mudanças ambientais que estão acontecendo" (NODARI; ESPÍNDOLA, 2013, p. 165). 
Para tanto, utilizamos fontes históricas diversas, como fotografias e jornais, no intento de reconstituir um tempo pretérito, mas que estabeleça uma ligação entre temporalidades. Em outras palavras, acionamos o passado como forma de perceber a cidade de São Sebastião do Caí na sua atualidade e a sua relação com o rio, já que o "exercício historiográfico, quando focado nas questões ambientais, deve estar aberto para a pluralidade de fatores que interferem na composição e no funcionamento do ambiente nas cidades" (RÜCKERT; HARRES, 2014, p. 37).

Conforme Wollmann e Sartori (2010), os sujeitos, depois de perceberem um fenômeno natural, passam a conhecê-lo para melhor poderem se relacionar com ele. A história oral, nesse sentido, é uma forma de reconstruir a história através dos depoimentos de moradores da cidade, podendo entender o que significa viver em uma região assolada por fenômenos naturais de grande impacto no cotidiano da população, como as enchentes do rio Caí. Importante considerarmos, ainda, que, através do estudo das percepções e dos valores, os historiadores podem refletir sobre o "mundo não-humano" (WORSTER, 1991, p. 210).

Entendemos, pois, que a utilização da história oral é pertinente, uma vez que uma totalidade concreta passada não pode ser alcançada em sua forma original, mas ser construida a partir de depoimentos e narrativas de pessoas que viveram o momento e o interpretaram a partir de suas vivências. Segundo Thompson (1998, p. 44), essa metodologia de pesquisa "traz a história para dentro da comunidade e extrai a história de dentro da comunidade". Além disso, os depoimentos das "pessoas comuns" podem ser considerados como uma "esfera oculta" da pesquisa histórica, pois eles estão inseridos em "aspectos da vida da maioria das pessoas que raramente são bem representados nos arquivos históricos" (THOMPSON, 2002, p. 17).

\section{A ocupação inicial}

O município de São Sebastião do Caí encontrase na região do Vale do Caí, formada, também, pelos municípios de Alto Feliz, Barão, São Vendelino, Vale Real, São Pedro da Serra, Salvador do Sul, Tupandi, Bom Princípio, Feliz, Linha Nova, Brochier, Maratá, Harmonia, Pareci Novo, São José do Sul, São José do Hortêncio, São Sebastião do Caí, Capela de Santana e Montenegro, conforme podemos observar no mapa da Figura 1.

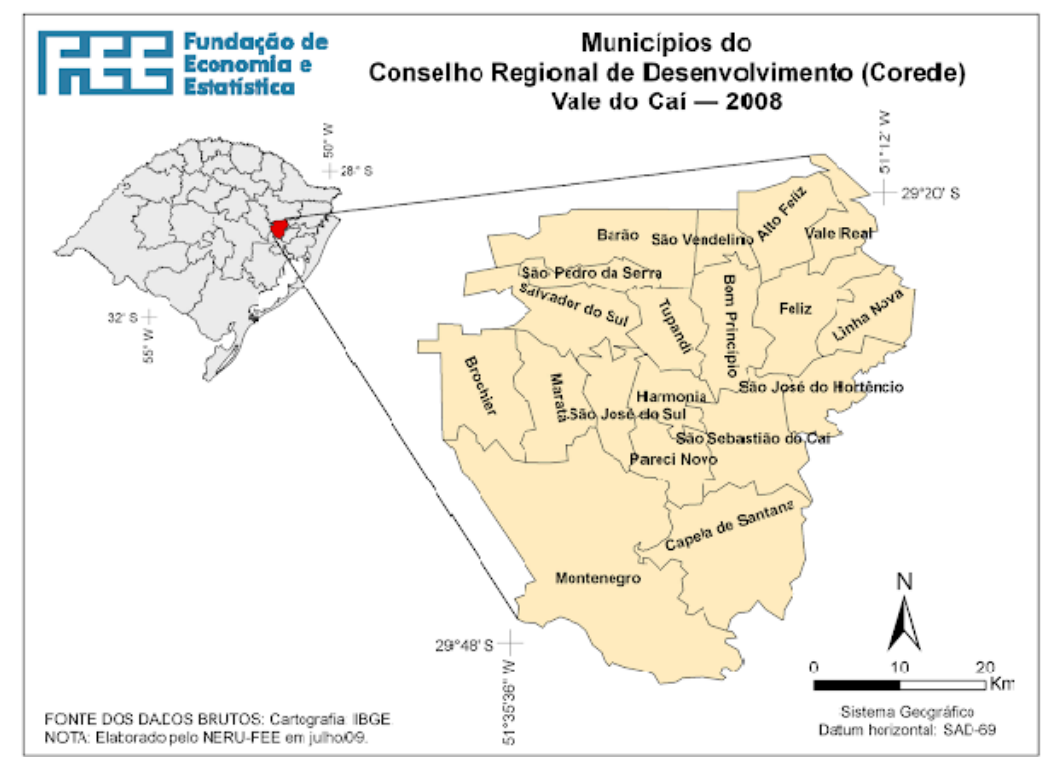

Figura 1 - Mapa da região do Vale do Caí Fonte: Site Histórias Vale Cai. ${ }^{2}$ 
Na formação histórica do município, encontrase a participação de indigenas, portugueses, negros, italianos e alemães. A arquitetura, expressa em diferentes prédios que estão presentes até hoje no cenário da cidade, atesta a influência lusa e germânica, sendo que a utilização de azulejos na decoração de fachadas e interiores é tipicamente portuguesa. Ao que tudo indica, os alemães tiveram uma participação importante nas alterações e mudanças na localidade, já que atuaram especialmente no cultivo de pequenas propriedades. De acordo com os estudos de Reinheimer (2010),

Foram os núcleos coloniais estabelecidos junto ao rio Caí que mais cedo prosperaram, formando vilas com apelo comercial [...] Também é certo que todas as colônias do rio Caí progrediram em função do intenso movimento em seus portos fluviais como nos de São Sebastião do Cai e de Montenegro. Isso ocorreu desde o início da colonização alemã e se intensificou após a fundação das colônias italianas na Serra, em 1874 (REINHEIMER, 2010, p. 39).

A relação entre ocupação europeia e alterações ambientais, sem dúvida, eram estreitas, posto que a colonização e o progresso "mentalidade vigente à época da colonização" auferia uma modificação no ambiente com derrubada de florestas, abertura de caminhos, cultivo de alimentos para o sustento dos colonos e para comercialização, entre outros (ESPINDOLA; NODARI, 2013, p. 168).

A respeito da derrubada de florestas, Warren Dean (1996) diz se tratar de um problema histórico no Brasil e que remete aos tempos da colonização e exploração do pau-brasil e, posteriormente, da cana-de-açúcar, da mineração, do café, chegando à industrialização. Ou seja, esse não é um problema exclusivo da região do Vale do Caí. Segundo Dean (1996, p. 23-24),

A história florestal corretamente entendida é, em todo o planeta, uma história de exploração e destruição. O homem reduz o mundo natural a "paisagem" - entornos domesticados, aparados e moldados para se adequarem a algum uso prático ou à estética convencional - ou também, o que é ainda mais assustador, a "espaço" - planícies desertas aplainadas a rolo compressor e sobre as quais o extremo do narcisismo da espécie se consagra em edificações.
O autor assevera que "as intervenções humanas quase nunca realizam as expectativas humanas", pois os campos e os pastos se empobrecem e as cidades entram em colapso, sendo que "o mundo natural, simplificado, em desacordo com os desejos humanos, mas em resposta a seus atos, converte-se em uma enorme macega cosmopolita de luto" (DEAN, 1996, p. 24).

Situações análogas a da região do Vale do Caí aparecem em diversas cidades do País e do exterior e, segundo Freitas e Ximenes (2012), as enchentes podem ser consideradas um dos impactos ambientais que mais afetam a vida das pessoas no mundo:

Dentre os inúmeros impactos ambien-
tais que afetam a vida de milhões de
pessoas no mundo, os eventos como
enchentes atingem cerca de 102 mi-
lhões de pessoas por ano e a maior
parte das populações expostas (95\%)
e dos óbitos (95\%) se encontram nos
paises de menor renda per capita (igual
ou menor que 3.705 dólares por ano).
Seus impactos são mais severos para
determinados grupos populacionais e
espaços geográficos mais vulneráveis,
seja nos paises mais pobres ou mesmo
nos paises mais ricos, como foi demons-
trado após o furacão Katrina (FREITAS;
XIMENES, 2012, p. 1602).

No território brasileiro, uma das cidades que mais sofre com o problema das enchentes é São Paulo. Segundo Alves Filho e Ribeiro (2006, p. 152),

As reportagens sobre as enchentes do
periodo [ano de 1983] passaram a apa-
recer com destaque na imprensa, rece-
bendo o statu de calamidades públicas.
As fotos do transbordamento dos rios
e das tragédias urbanas começaram
a estampar reportagens de capa dos
principais periódicos. Ao mesmo tempo,
apresentavam-se os recordes de vazão
de cheia na Bacia do Alto Tietê sendo
vencidos. Nesta época, [...] a desorgani-
zação urbana, durante os principais epi-
sódios, chegou a impedir a circulação de
pessoas e de mercadorias, com o extra-
vasamento dos rios e com seccionamento
da metrópole, tal como numa guerra civil,
provocando sofrimento e morte para as
populações menos assistidas.

Os dados que esses autores apresentam vêm ao encontro das informações de Freitas e Ximenes (2012), no que diz respeito às vítimas desses desastres: 
No episódio de 05 e 06 de fevereiro de 1982 [na cidade de São Paulo], registraram-se dez mortos, 1.613 pessoas desabrigadas, sendo que, destas, 642 perderam suas casas. Já, entre 04 e 05 de junho de 1983, ficaram desabrigados 1078 pessoas, 15 morreram vitimados pelas enchentes e por deslizamentos em áreas de risco. Foram 63 ocorrências de desabamentos e soterramento de barracos, vitimando principalmente os moradores de favelas (ALVES FILHO; RIBEIRO, 2006, p. 153).

Esses mesmos problemas são frequentes e recorrentes, também, na cidade do Rio de Janeiro. Conforme Costa et al. (2018, p. 22):

O crescimento da cidade esteve (e está) diretamente relacionado a grandes intervenções no ambiente, o qual naturalmente já apresenta um grau de instabilidade elevado, em função de suas características climáticas, geomorfológicas e hidrológicas. Daí, pode-se afirmar que o processo de urbanização intensificou a questão das enchentes urbanas no município.

No caso da localidade em estudo, a cidade de São Sebastião do Caí, o processo de colonização também acarretou em modificações ambientais. Destaca-se, nesse sentido, a importância dos portos locais, vitais para a sobrevivência e o desenvolvimento das colônias que se fixavam às margens dos rios na primeira fase da imigração no Brasil (1824-1889).

A importância do rio para a localidade fica clara no próprio significado do seu nome. "Caa" significa mato e "y" quer dizer água, portanto, Caa-y quer dizer "água do mato" ou "rio da mata". São Sebastião juntou-se ao nome do município somente anos mais tarde, mais precisamente em 1873, devido ao santo padroeiro (ESTEVES,2002 apud GALLAS, 2014).

Não obstante à proximidade física das colônias alemãs com o rio e o porto, São Sebastião do Caí foi relevante para alavancar o desenvolvimento das novas colônias italianas que se instalariam após 1875 na serra gaúcha. Do ponto de vista logístico, o porto do Caí serviu para abastecer e ser o entreposto entre a capital e a serra, demarcando o último ponto de acesso fluvial para as colônias de imigrantes italianos.
No tocante aos imigrantes, inicialmente os alemães, que se expandiram do Vale do Rio dos Sinos para o Caí, o histórico não difere de outras espacialidades, ou seja, esses imigrantes encontraram dificuldades de adaptação às condições climáticas e geográficas, bem como problemas com a demarcação dos lotes e muitos empecilhos constitucionais para o cumprimento da naturalização imediata.

O avanço da circulação de mercadorias na localidade, associado às perspectivas de colonização e, principalmente, à produção de produtos agrícolas oriundos das pequenas propriedades, promoveu e incentivou a instalação do Porto Guimarães, às margens do rio Caí. Aos poucos, a localidade foi adquirindo importância devido à via fluvial, já que servia como caminho para transportar produtos coloniais cultivados e produzidos na região e que escoavam até Porto Alegre (ESTEVES, 2002).

A produção das pequenas propriedades dos imigrantes resultou na expansão do porto e, consequentemente, na montagem de uma infraestrutura comercial na localidade de São Sebastião do Caí, já que possibilitou o escoamento da produção agrícola pelo Rio Caí para a população provinciana por Porto Alegre e, inclusive, para exportação. Nesse sentido, a agricultura desenvolvida pelas famílias de imigrantes contribuiu significativamente para o abastecimento interno da província e resultou em avanços para as localidades interioranas. Importante considerarmos, também, que "a área banhada pelo Rio Cai e seus afluentes é contígua à dos Sinos. Foi a segunda área a constituir colônias de imigração no Rio Grande do Sul, o que ocorreu a partir de 1846, com a criação da colônia de Bom Princípio" (REINHEIMER, 2010, p. 39). Podemos dizer, assim, que as vias fluviais, especialmente do Rio Caí, subsidiaram o avanço local e regional, bem como possibilitaram condições de sustento e melhor renda para os moradores da região.

\section{A cidade, seu porto e seu rio}

A vila que se emancipou em $1 .^{\circ}$ de maio de 1875 havia progredido nos últimos anos devido à importância do seu porto, pois era por ele que 


\section{6/16}

Estudos Ibero-Americanos, Porto Alegre, v. 46, n. 1, p. 1-16, jan.-abr. 2020 | e-33872

escoavam os produtos da região, especialmente os de São José do Hortêncio, estabelecida em 1848 e primeira colônia alemã a ser fixada no Vale do Rio Caí, que passaria a receber muitos colonos do Vale do Sinos. O desenvolvimento das práticas comerciais ajudou a fazer a expansão do porto e, consequentemente, da vila que se emancipara do município de São Leopoldo.

Na Figura 2, podemos observar que o porto, no final do século XIX, era ainda bastante rudimentar, mas a área em seu entorno já apresentava construções.

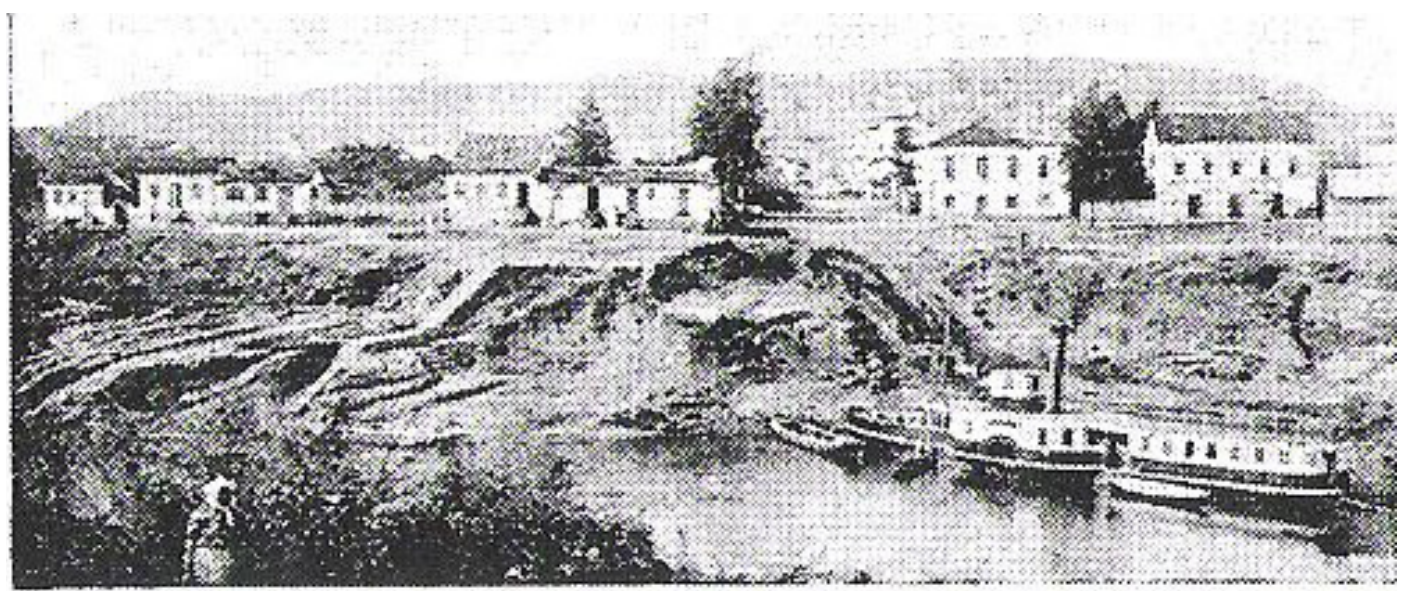

Figura 2 - Porto em data aproximada de 1900

Fonte: Site História Daqui. ${ }^{3}$

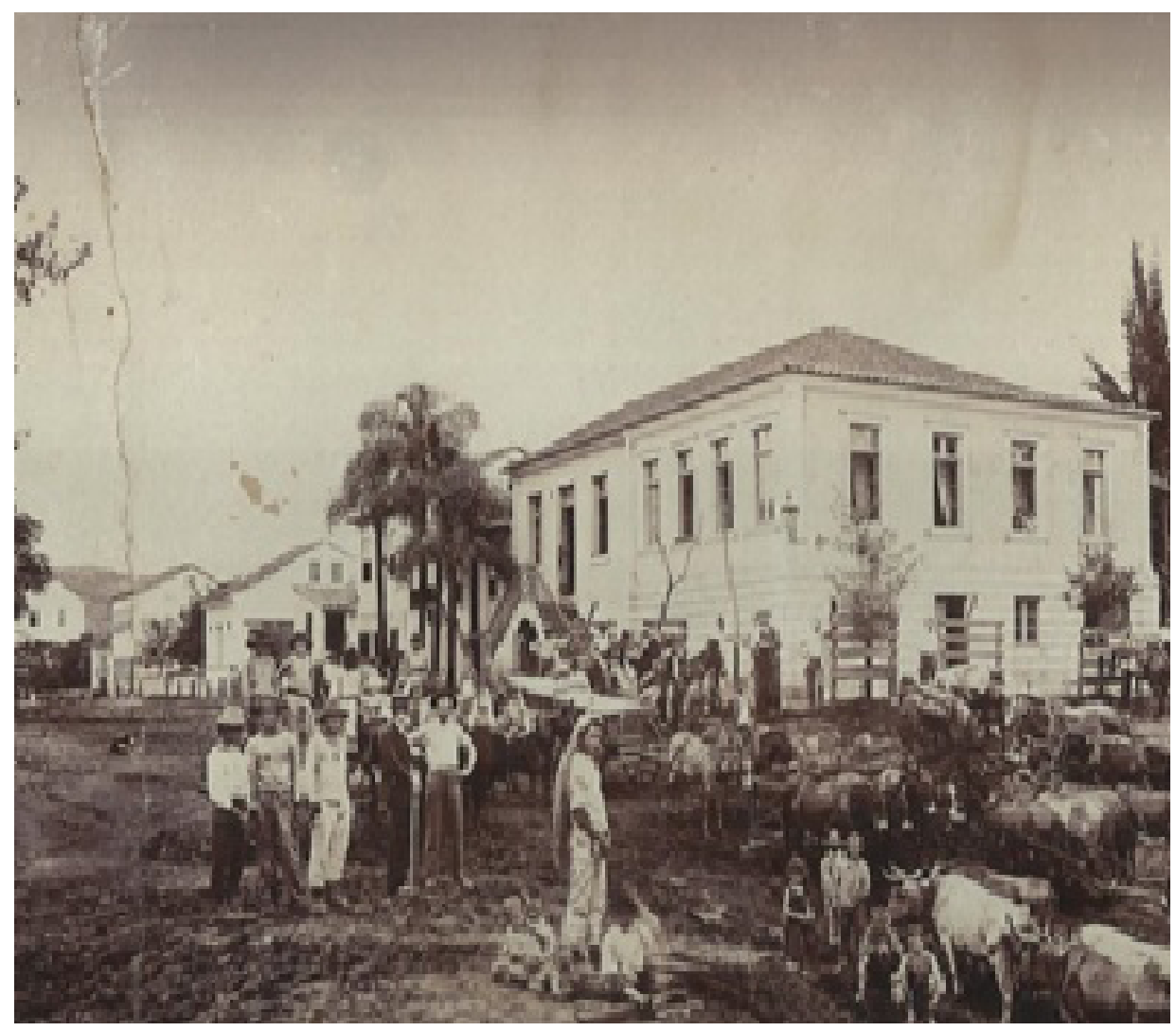

Figura 3 - Cais do porto

Fonte: Acervo do Museu Histórico Vale do Cahy.

3 Disponivel em: http://historiadaqui.blogspot.com.br/2011/12/era-uma-vez-um-distrito-de-sao.html. Acesso em: 20 jul. 2016. 
Nesta última imagem (Figura 3), podemos ver a quantidade de carretas e de animais de tração, como mulas, cavalos e bois, que indicavam a necessidade dos mesmos para o transporte terrestre de produtos e de pessoas nas estradas na área colonial. A imagem também chama atenção pelo grande número de individuos que, provavelmente, trabalhavam na condução dos produtos coloniais via terrestre até o porto do Rio Caí, bem como no carregamento e no embarque da produção que escoava via curso d'água para outras localidades, como Porto Alegre, demonstrando a sua importância econômica para a zona colonial.

A navegação pelas águas do Caí e o desenvolvimento do comércio local fez com que São Sebastião do Caí se tornasse o centro de negócios da região e fosse reconhecida como cidade em 1939. Para Schröder (2014, p. 42):

A navegação possibilitou o desenvolvimento do comércio de tal forma que São Sebastião do Caí passou a ser o grande centro de negócios da região. A produção da zona de colonização alemã, do Vale do Caí e da italiana, na Serra, era levada em carretas ou lombo de burro até o porto da cidade e dali era conduzida de barco a Porto Alegre e arredores. Sendo assim, o Cai se tornou "mãe" de vários municipios vizinhos que depois emanciparam-se.

Podemos dizer que a história de São Sebastião do Caí foi construída ao longo de um rio, o mesmo que fez a cidade nascer, visto que, "com o passar do tempo, os espaços em torno dos rios foram sendo desenvolvidos e surgiram as primeiras cidades" (SCHRÖDER, 2014, p. 17). Mello (2008, p. 300), por sua vez, destaca que:

No modelo predominante de formação das cidades brasileiras, por um lado, as curvas de nivel moldadas pelas calhas dos corpos hidricos estruturaram o traçado urbano. Por outro, na maioria dos casos, lotes, edificações e principais atividades de caráter público não se voltavam para as margens. Para elas voltavam-se os fundos de quintais e espaços sem destinação, caracterizando desde cedo a vertente urbana de desvalorização dos corpos d'agua.

O porto e a cidade têm, pois, uma simbiose natural, assim como o rio que sustenta, enriquece a cidade e a região e, ciclicamente, também a engole com suas cheias. ${ }^{4} \mathrm{~A}$ convivência é marcante em todos os periodos da história, pois o mesmo rio que leva e traz as pessoas e as mercadorias, de tempos em tempos, cobra da cidade a invasão de seu território de expansão natural.

Essa questão do avanço das águas, além da sazonalidade do regime de chuvas na região, guarda relação, também, com a ocupação humana. O desmatamento das áreas ribeirinhas e a consequente ocupação animal e humana foram agravando as condições do rio em toda a sua extensão, especialmente, com o seu assoreamento, fruto do desmatamento, do uso inapropriado do solo, do descuido das margens e dos próprios ciclos naturais. Conforme Sakai (2014, p. 4):

Os cursos d'água nas cidades devem
ser percebidos tanto pela sua dimensão
social, quanto pela sua dimensão am-
biental trabalhadas integralmente, por
isso o discurso ambiental na cidade não
deve ser exclusivamente sobre o verde,
associado ao sentido natural purificado,
mas do ambiente seguro e promotor da
qualidade de vida de todos.

No acervo do Museu Histórico Vale do Cahy, encontramos imagens que apresentam o barco a vapor, que levava, no final do século XIX e início do século $X X$, passageiros e mercadorias (Figura 4) até Porto Alegre. O porto era núcleo da economia caiense, o que podemos observar pela imagem a seguir:

\footnotetext{
4 Utilizamos a palavra "cheia" como sinônimo de "enchente", que significa temporária elevação do nivel d'água normal da drenagem devido a acréscimo de descarga, e que é diferente de "inundação", que seria um tipo particular de enchente, na qual a elevação do nível d'água normal atinge tal magnitude que as águas não se limitam à calha principal do rio, extravasando para áreas marginais, habitualmente não ocupadas pelas águas (http://www.rc.unesp.br/igce/aplicada/ead/riscos/risco15.html). Acesso em: 17 jul. 2016.

Para mais informações a esse respeito, ver:_GOERL, Roberto Fabris; KOBIYAMA, Masato. Considerações sobre as inundações no Brasil Disponivel em: http://www.labhidro.ufsc.br/Artigos/ABRH2005_inundacoes.pdf. Acesso em: 17 jul. 2019
} 


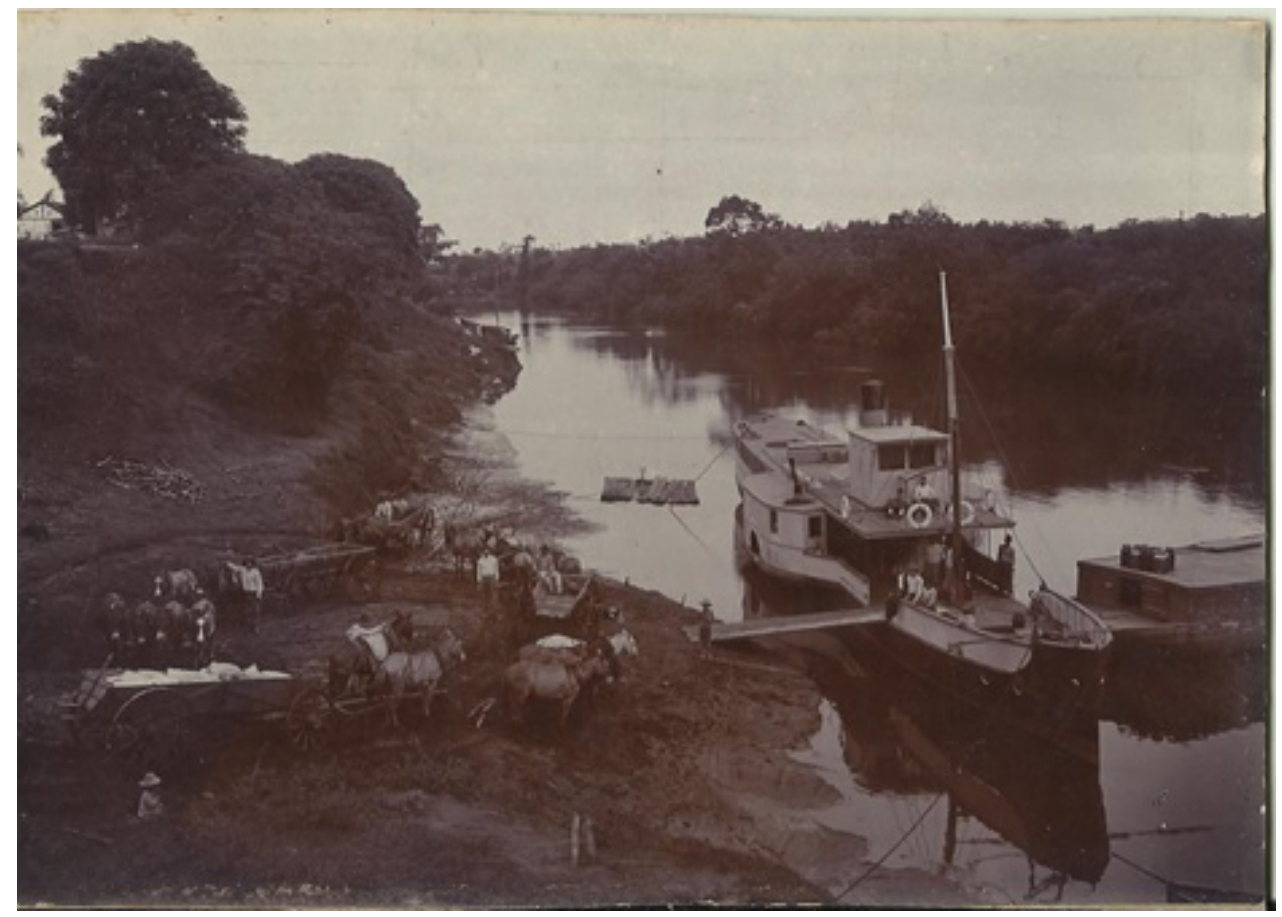

Figura 4 - Cais do Porto (1888)

Fonte: Acervo Museu Histórico Vale do Caí.

Como bem lembra Pesavento (2008, p. 106), "as imagens possuem poderes bem definidos: são sedutoras, captando o olhar, de modo a envolver aquele que a contempla; são mobilizadoras". A imagem (Figura 4) corresponde ao ano de 1888 e registra a importância do porto localizado na cidade, com as tábuas que serviam como rampas para o embarque e desembarque de pessoas e produtos nos vapores. Já a quantidade de mulas permite pensarmos na quantidade considerável de produtos deslocados até o porto (GALLAS, 2014).

O rio foi o vetor inicial do desenvolvimento e o seu papel somente perderia espaço com o desenvolvimento das estradas e da indústria automobilística nacional. Uma passagem do Jornal $\mathrm{NH}$ de 1997, ano em que o município completava os seus 122 anos de emancipação, mostra-nos a importância do Rio Cai para a cidade:

Uma estrada de chão batido, com mato dos dois lados e um silêncio só quebrado pelo som das patas dos jumentos e do ranger das rodas do carroção que leva produtos agrícolas. Ao longe, o som de um barco a vapor e o murmurinho das pessoas anunciam a proximidade do cais do porto, onde os produtos da colônia são embarcados para Porto Alegre, para serem vendidos. Diversas pessoas também sobem a bordo para seguir viagem à capital do Estado. Essa cena, embora parecendo descrever um porto atualmente perdido da selva, num lugar qualquer, fazia parte de São Sebastião do Cai nos primeiros anos de sua história (RIO CAİ, 1997).

Essa descrição do porto de São Sebastião do Cai remete-nos ao cotidiano desses moradores e à importância do antigo cais do porto, atualmente localizado em uma região fora do centro de movimentação da cidade, e que, por muito tempo, moveu a economia do municipio e região. Acionamos aqui o entendimento da cidade como um "objeto de múltiplos discursos e olhares, que não se hierarquizam, mas que se justapõem, compõem ou se contradizem, sem por isso serem uns mais verdadeiros ou importantes que os outros" (PESAVENTO, 2002, p. 9).

$\mathrm{Na}$ Figura 5, podemos observar que, ao longo dos anos, o comércio e a circulação prosperavam, diversificando os produtos escoados via porto. A foto apresenta barcos cada vez maiores, como um barco a vapor (à esquerda na imagem) e algumas embarcações de pequeno calado, como as chatas, carregadas de produtos, como madeira, que foram muito relevantes para a economia local e regional. 


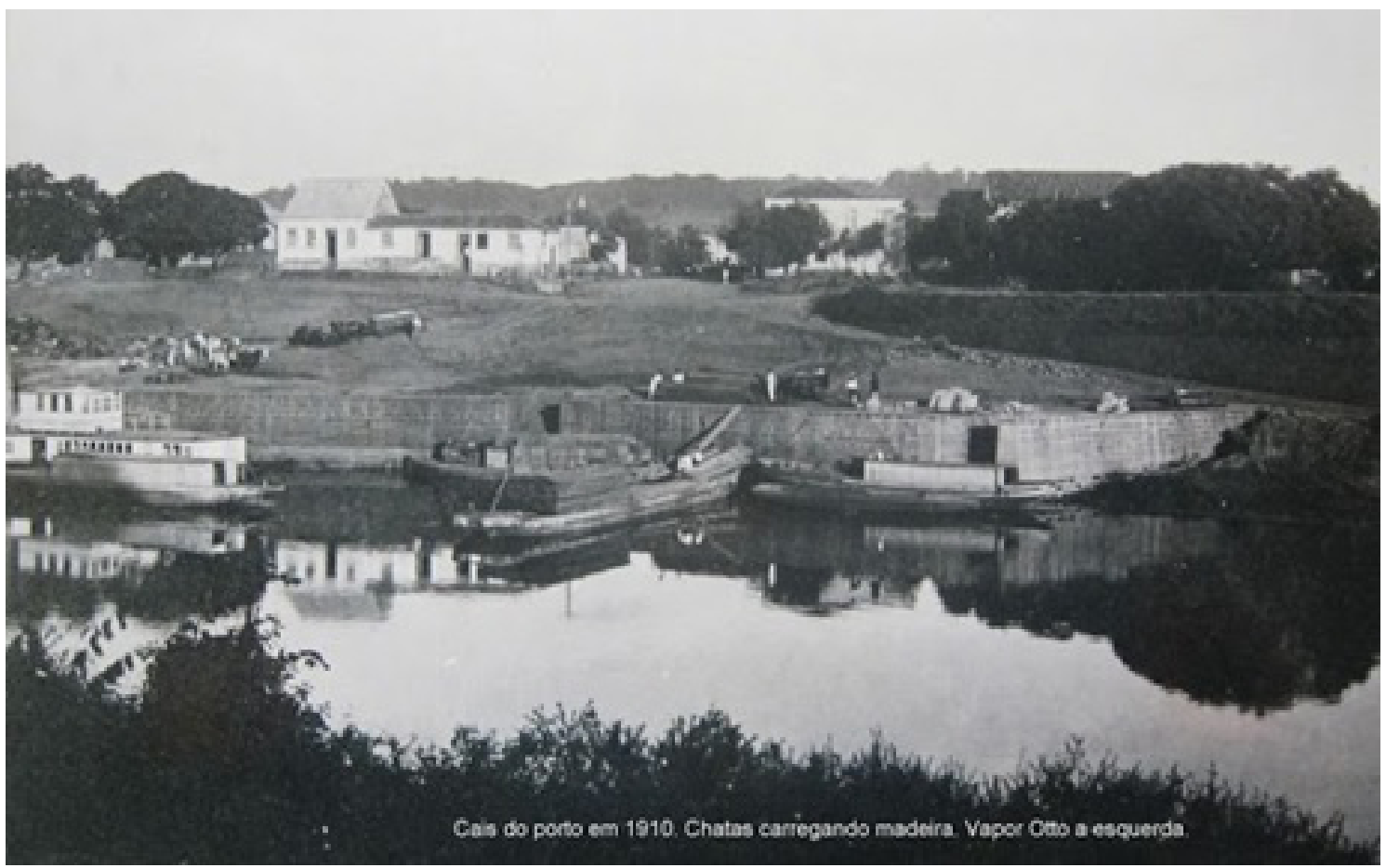

Figura 5 - Cais do porto (1910)

Fonte: Jornal O Fato Novo.

No final do século XIX e início do XX, eram inexistentes ou mesmo precárias as estradas que ligavam a capital a quase todas as regiões do Estado, o que não era diferente em relação ao Vale do Cai e tornava o rio fundamental para a circulação de pessoas e mercadorias. Assim, o rio Caí, mesmo sendo raso e não permitindo a navegação em qualquer época do ano, era, ainda, a melhor opção para o transporte de cargas.

Essa dependência climática, ou seja, a navegação somente era possivel quando o rio estava suficientemente cheio, dificultava a circulação da riqueza por esse meio e criava uma sazonalidade comercial e dificuldades aos produtores locais e regionais. Essa situação somente se normalizaria com a construção do sistema de eclusas e da barragem, no início do século $X X$, o que permitiu que a navegação se tornasse possivel em qualquer época do ano. $O$ complexo da eclusa e da barragem veio junto com outras melhorias, que possibilitavam a navegação constante no rio. Essa obra de engenharia foi o primeiro mecanismo desse tipo construido no Brasil e, provavelmente, na América do Sul (HISTÓRIAS DO VALE DO CAÍ, 2010).

Podemos certificar que a navegação foi de extrema importância para o desenvolvimento da região do Vale do Cai e da Serra Gaúcha, visto que, entre 1920 e 1930, toda a movimentação de mercadorias e passageiros de São Sebastião do Caí a Porto Alegre ocorria via fluvial, nas "gaiolas", que eram barcos movidos a vapor com duas caixas d'águas movidas por pás giratórias. Grandes empresas de navegação construiram seus armazéns ao longo do cais, os quais eram abastecidos pelos produtos coloniais e embarcados, posteriormente, nos barcos a vapor. Quando o transporte de mercadorias passou a ser realizado por terra, as companhias de navegação passaram a transportar pessoas de uma margem a outra, como registrado na Figura 6. que mostra um grupo de aproximadamente 20 pessoas aguardando para realizar a travessia (GALLAS, 2014). 


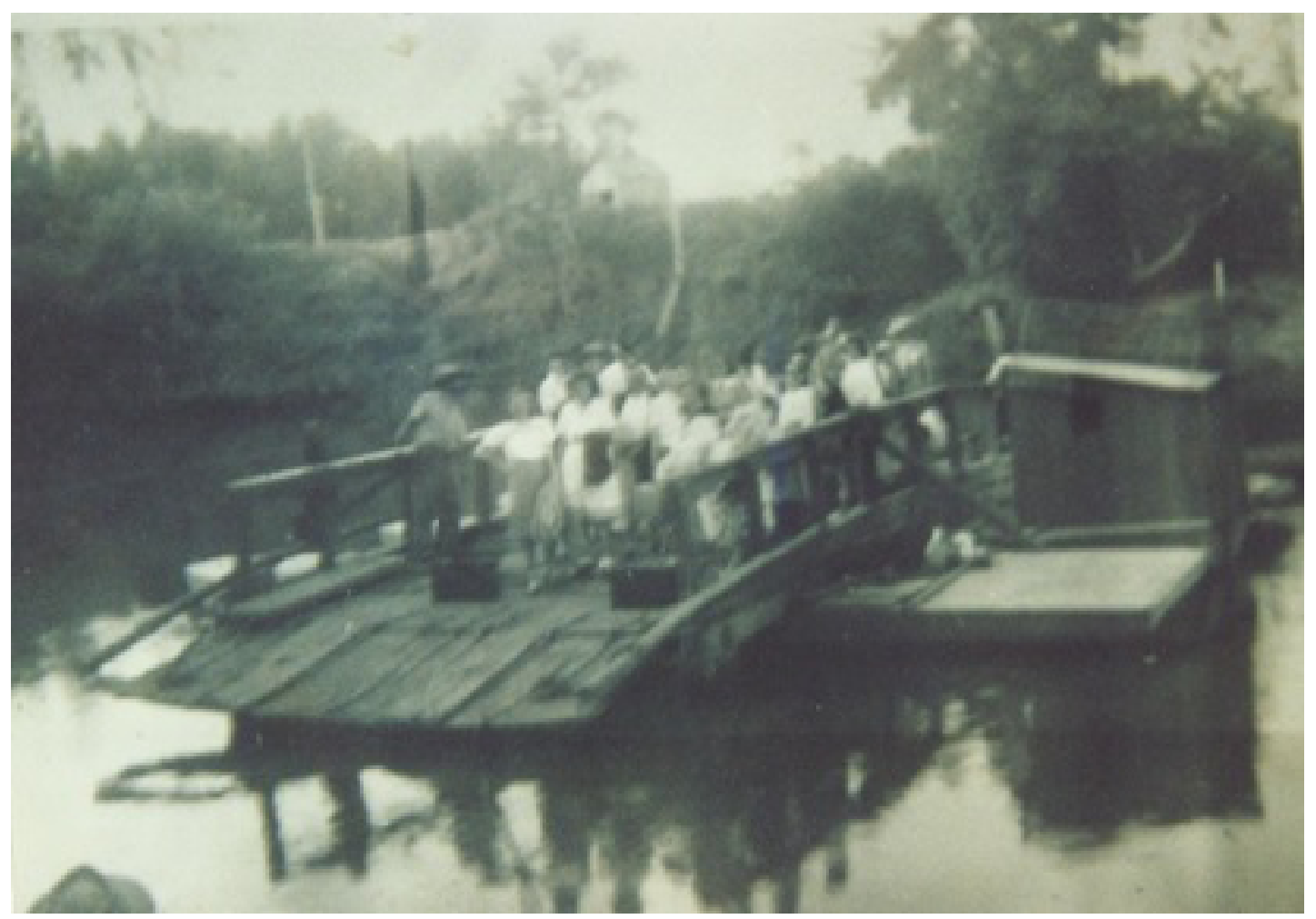

Figura 6 - Barca fazendo a travessia entre Matiel e Caí

Fonte: Acervo do Museu Histórico Vale do Cahy.

O rio e suas margens servem de espaço de sociabilidade até os dias de hoje, porém não da mesma forma e com a intensidade com que foi até o final dos anos 1990, quando as pessoas se reuniam em suas margens com amigos e familiares para banhar-se e realizar piqueniques. Atualmente, devido à poluição das suas águas, essa é uma prática que vem se perdendo cada vez mais entre os moradores (GALLAS, 2014).

Ao mesmo tempo em que o rio servia de espaço de lazer, ele também representava um sério problema na época das cheias, principalmente para a população ribeirinha. Segundo Mello (2008, p. 33):

Os processos de ocupação das "várzeas", "baixadas", "ribeiras" são constatáveis ao longo de nossa história [...] Esses processos, intensificados a partir de fins do século XX, não foram acompanhados por soluções compativeis de saneamento e infraestrutura, agravando os problemas socioambientais. No modelo que privilegia o transporte automotivo, tornou-se comum a ocupação dos fundos de vale por vias urbanas. Muitos espaços ribeirinhos de nossas cidades guardam ainda a degradação resultante da exploração econômica, do periodo industrial entre os séculos XIX e XX, quando eram os sitios mais propícios para a instalação de plantas industriais, estações de geração de energia e complexos portuários.

As enchentes afetam consideravelmente a vida da população, o que não deixa de fazer parte da identidade do municipio de São Sebastião do Caí, uma vez que esse sempre é associado à enchente. Na fotografia da Figura 7, provavelmente dos anos 1940, podemos perceber o avanço do rio sobre a cidade e um barco atracado onde normalmente circulavam carros e pessoas. 


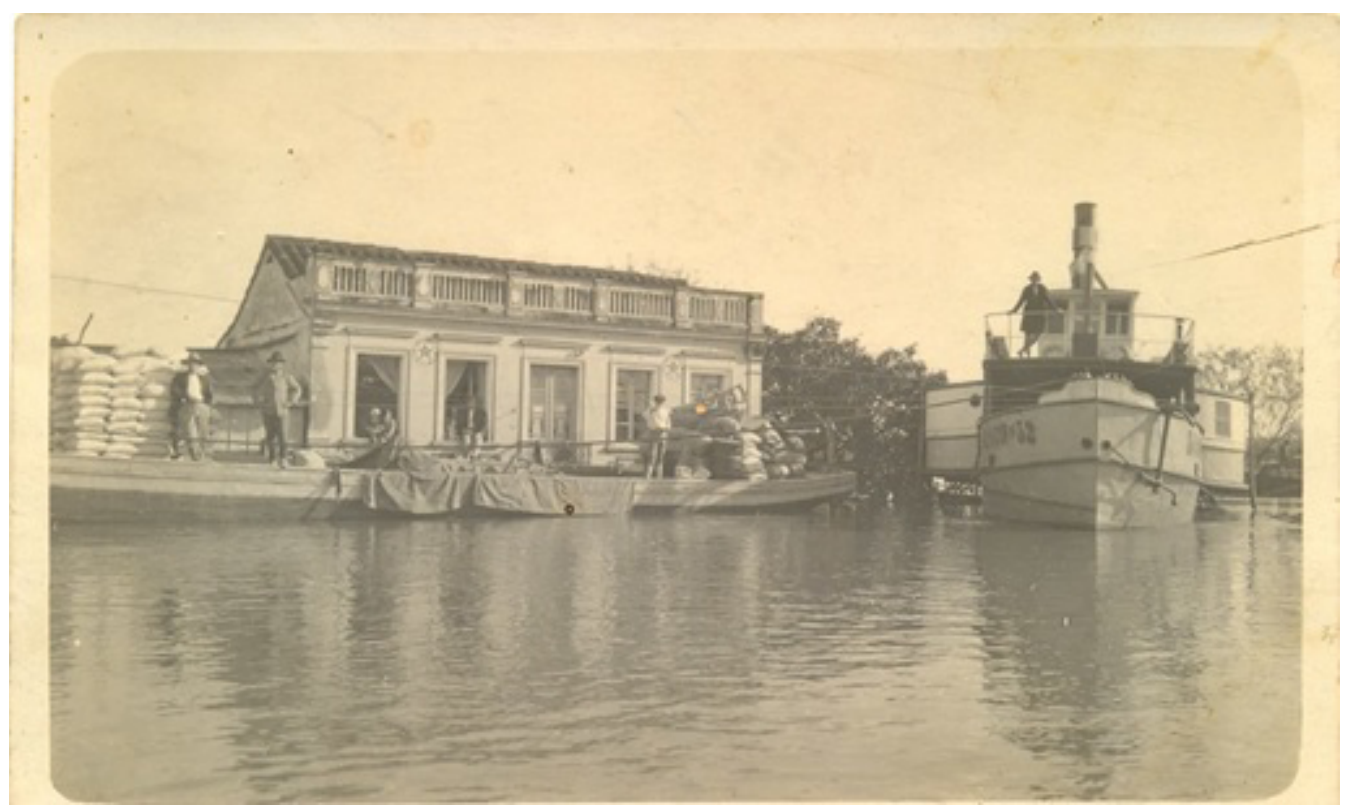

Figura 7 - Enchente anos 1940

Fonte: Página "Fotos antigas do Vale do Cai" 5

Para termos uma ideia das proporções que o nivel do Rio Caí, ainda em tempos atuais, atinge, apresentamos a imagem a seguir (Figura 8), que retrata a enchente de 1982 e que mostra as águas invadindo as ruas da cidade.

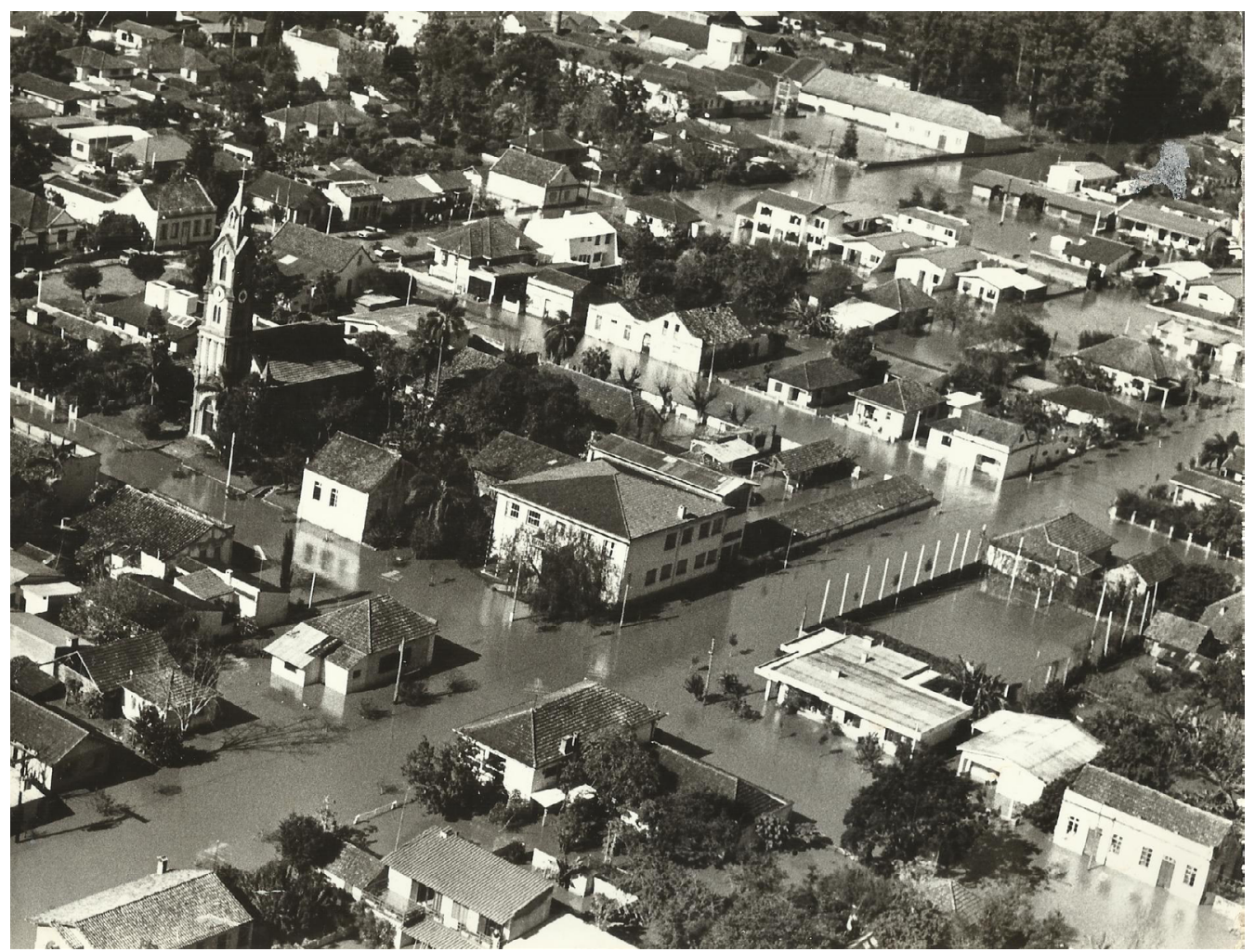

Figura 8 - Enchente de 1982

Fonte: Acervo do Museu Histórico Vale do Cahy.

5 Disponivel em: FOTOS antigas do Vale do Cai. Disponivel em: https://pt-br.facebook.com/Fotos-Antigas-do-Vale-do-Ca\%C3\%AD-658017280894713/. Acesso em: 02 jul. 2016 
Essa imagem mostra o centro da cidade, que não está localizado nas margens do rio, muito atingido pela enchente de 1982, que fora considerada a mais severa para o município, até o ano de 2011, quando as cheias foram ainda piores, atingindo 14,80 metros (GLAESER, [2018]).

De acordo com Baptista (2013, p. 126):

As respostas dos sistemas fluviais urbanos - naturais ou construidos - não tardaram a vir: Em um cenário pontuado pela concentração da população em cidades e pela identificação populacional em grandes metrópoles, com a frequente ocupação de áreas de risco por habitações subnormais, os prejuizos ambientais e danos socioeconômicos severos decorrentes de inundações colocam em questão os modelos de urbanização e sanitários vigentes. Atualmente, constata-se o início de uma nova fase nesse relacionamento das cidades e seus rios. A tomada de consciência das grandes questões ambientais, cada vez mais presente, e a contabilização dos danos socioeconômicos faz com que a questão da restauração fluvial passe a integrar as pautas de reivindicações da sociedade [...].

A matéria veiculada no jornal Primeira Hora (LIXO..., 2015, p. 20) apresenta o drama das famílias ribeirinhas, que são mais vulneráveis mediante as cheias do Caí, pois a enchente de 2015 desabrigou 39 familias. O periódico ainda ressalta que as águas atingiram 12,82 metros, forçando o deslocamento de moradores que habitavam próximo do rio para abrigos. A imprensa também alertava para a dificuldade do escoamento das águas, devido à quantidade significativa de lixo acumulado, indicando que chinelos, sacos plásticos, entre outros se espalhavam e dificultavam o escoamento das águas do Caí.

Sobre a relação com o rio Caí e a importância do mesmo em outros tempos, utilizamos diversos depoimentos, que nos dão a medida exata do impacto do rio e suas cheias sobre a população caiense. A fala dos entrevistados traz à tona memórias pessoais, que são também memórias sociais, familiares e grupais, estão na fronteira entre os modos de ser do indivíduo e de sua cultura (BOSI, 1999).
De acordo com Bosi (1999), "o instrumento decisivamente socializador da memória é a linguagem [...]. As convenções verbais produzidas em sociedade constituem o quadro ao mesmo tempo mais elementar e mais estável da memória coletiva" (BOSI, 1999, p. 56) e, diz, ainda, que, "cada geração tem, de sua cidade, a memória de acontecimentos que permanecem como pontos de demarcação em sua história" (BOSI, 1999, p. 418).

Citamos como exemplo o que relata um morador que relembra a sua infância, quando ele e os irmãos banhavam-se nas águas do rio, enquanto o padrasto pescava, o que completava a alimentação da família. Ao mencionar seu tempo passado, o entrevistado aponta que as enchentes deixavam os adultos nervosos, mas não as crianças, pois era motivo de alegria, já que o rio se aproximava ainda mais (ADELS, 2016, informação verbal) ${ }^{6}$.

Contudo, ao se referir ao tempo presente, o entrevistado ressalta que existem os "outros" perigos que envolvem o Caí, além de suas cheias e da poluição. Questionado acerca dos perigos, nosso interlocutor indica que as áreas próximas ao rio, que outrora serviram de espaço de sociabilidade para a comunidade em geral e para a prática da pesca, hoje é espaço de drogadição, posto que usuários de drogas ocupam o espaço, o que afasta muitos moradores da cidade de usufruir do rio.

Ainda, segundo esse depoente, "o rio Caí aparece na televisão por causa das enchentes e não acho mais divertido como na minha infância, agora fico preocupado, já que as enchentes chegam a $14 \mathrm{~m}$ e forçam muitas familias a se deslocarem para alojamentos até a água baixar" (ADELS, 2016, informação verbal)7. Além da saida da moradia, a maioria das pessoas que necessitam se abrigar nos alojamentos perde para as águas do Caí seus bens móveis, além de roupas, alimentos, entre outros.

Em outro depoimento, a importância do rio para a cidade é acionada paralelamente com os "sustos" que suas águas, em periodo de cheias, ocasionamà população. A sua fala que reforça nossa observação 
da degradação ambiental e das mudanças climáticas do planeta8: "todos os anos tem enchente no Caí e nos últimos anos são maiores".

Para esse depoente, as cheias com maior volume de água, as quais atingem altura cada vez maior, são associadas ao fato de que "tem muita gente aterrando alguns lugares [...] aí o rio sobe e vai para onde é mais baixo". O entrevistado lembra que, na sua infância, era responsável pelos cuidados com a sobrinha, enquanto o irmão, juntamente com o pai, carregava os móveis do andar inferior da casa para o superior. Menciona que, atualmente, em sua residência, as cheias atingem a parte da frente e dos fundos da sua propriedade, "ficamos ilhados", "mas a água não entra na casa" (PILGER, 2016, informação verbal).

A memória dos entrevistados permite-nos perceber São Sebastião do Caí como uma cidade que forma unidades de tempo e espaço, pois apresenta reminiscências acerca de uma cidade vinculada ao seu rio, que atua de forma significativa na vida cotidiana das pessoas, com seus benefícios e com seus "sustos". De forma direta ou indireta, atingidos ou não pelas cheias do Caí, os moradores acabam tendo uma relação muito próxima com o rio, posto o espetáculo das suas águas estar intrinsecamente presente na construção histórica local.

As enchentes historicamente mobilizam os moradores do município, que, mesmo sendo uma calamidade da natureza, podem ser vistas como um evento local, promovendo a solidariedade entre os moradores, já acostumados com esses acontecimentos constantes, que "constituem-se como fato natural e cultural ao mesmo tempo, sendo assim um traço distintivo da identidade local" (SCHRÖDER, 2013, p. 16). Dessa forma, podemos entender que "a identidade não é o resultado fechado de heranças culturais, mas a produção contínua e dolorida de criações diárias, inseridas no jogo social" (CAMPOS; FLORES, 2007, p. 271).

Para quem deixou São Sebastião do Caí, a lembrança de sua vida na cidade é reveladora da relação com o rio. O depoimento de Getúlio Alberto Schemes (informação verbal) 9 ilustra, de maneira instigante, essa relação:

Tenho uma lembrança da minha in-
fância, nunca fomos desalojados pela
enchente, mas recebiamos em casa
as pessoas que saíam de suas casas.
Lembro de uma primeira casa onde
moramos na rua Tiradentes, ali quando
a água subia sempre tinha uma familia,
os Welter, que moravam no início da rua
mais perto do rio e que sofriam primeiro.
Depois mudamos para outra casa, na
vila "sapo" atrás da cadeia. Era uma casa
mais alta, tinha um porão alto. Também
não lembro de água entrando nela, mas
da movimentação das pessoas que
fugiam da enchente e que procuravam
abrigo em outras casas.

A fala de Schemes é reveladora, pois identifica que a relação com o rio, especialmente nas cheias, tocava os moradores, pois, mesmo aqueles que não eram atingidos pela água, se envolviam com a comunidade e com os desdobramentos causados pela cheia e a sua alteração do cotidiano.

A reconstrução da memória, como podemos perceber nesse e em outros depoimentos, deuse a partir de dados e noções comuns entre os depoentes, pois os mesmos fizeram parte de uma mesma sociedade e de um mesmo grupo e, segundo Pollak (1989, p. 9), a memória é uma operação coletiva dos fatos ocorridos e interpretados que se quer "salvaguardar" como objetivo de "definir e reforçar sentimentos de pertencimento e fronteiras sociais entre coletividades." As lembranças e rememorações abordadas no presente estudo trazem à tona a relação estreita entre a cidade de São Sebastião do Caí e seu rio, bem como mostra que ambos estão presentes e vinculados à história e à memória de quem convive ou conviveu em algum momento

\footnotetext{
8 Segundo o Painel Intergovernamental sobre Mudanças Climáticas (IPCC), criado pelo Programa das Nações Unidas para o Meio Ambiente (ONU Meio Ambiente), para sintetizar e divulgar informações científicas sobre as mudanças climáticas, estas representam um dos "maiores desafios do nosso tempo, pois seus impactos, que afetam desde a produção de alimentos até o aumento do nível do mar - aumentando o risco de inundações catastróficas - têm desestabilizado as sociedades e o meio ambiente de uma maneira global e sem precedentes" (https://nacoesunidas.org/acao/mudanca-climatica/). Para mais informações sobre enchentes e inundações, ver: LICCO. Eduardo Antonio: SMAC DOWELL, Silvia Ferreira. Alagamentos, Enchentes Enxurradas e Inundações: Digressões sobre seus impactos sócio econômicos e governança. Disponivel em: http://www.sp.senac.br/blogs/revistainiciacao/wp-content/uploads/2015/12/110_IC_artigo-.pdf.

9 Informação por meio de entrevista com SCHEMES, G. A., concedida à entrevistadora C. Schemes, em Novo Hamburgo, em agosto de 2018
} 
com o Rio Caí e todas as suas manifestações.

A história do município de São Sebastião do Caí está, pois, intimamente ligada ao rio e as memórias dos seus moradores reforçam uma constituição identitária local que relaciona passado e presente, sendo que, em ambas as temporalidades, a presença de suas águas é constante. O rio, que outrora favoreceu a riqueza da região e da cidade de São Sebastião do Caí com o seu caminho fluvial, através do escoamento de produtos locais para a capital sul-rio-grandense, foi um espaço dinâmico para além das questões econômicas, posto que também incentivava as relações sociais a partir de momentos de sociabilidade.

Atualmente, o rio parece ser lembrado pela importância de fornecer água para a localidade (para consumo ou para a economia), bem como pelas suas cheias, que causam transtornos, principalmente para os moradores em situação de vulnerabilidade. Com o processo de urbanização, a relação entre o rio, a cidade e os seus moradores foi se transformando, ou seja, as interações entre os sistemas sociais e naturais foi se modificando e, como ocorre em muitas cidades brasileiras, a cidade virou as costas para o rio e ele se transformou, de agenda de desenvolvimento, à problema ambiental.

\section{Considerações finais}

A história e a sua relação com o tempo permitem-nos "navegar" pelo curso de águas e a sua relação com o homem, as suas elaborações e construções. A cidade de São Sebastião do Caí e os seus personagens sinalizam para a relação próxima de um espaço fluvial e a constituição de um cenário histórico rico com diferentes personagens e participações. O estabelecimento de diferentes etnias ao longo das margens do rio Caí, desde o início de sua história, indica-nos a sua importância. Os estudos apresentados ao longo deste trabalho demonstram que a localidade de São Sebastião do Caí está relacionada ao porto, estabelecido em seu principal rio, uma vez que o escoamento de produção agrícola, principalmente a partir da presença de diferentes imigrantes, alavancou não só a economia e o desenvolvimento local, como também beneficiou o estado do Rio Grande do Sul.

Nesse sentido, corroboramos Baptista (2013. p. 125), ao afirmar que as "intervenções em cursos de água urbanos tem sido foco de amplo debate nos dias de hoje, com destaque para o tema da restauração", ou seja, a recuperação das questões histórico, culturais e ambientais ligadas ao rio. O autor ainda diz que "as tendências atuais apontam para uma maior integração desses meios ao cenário das cidades, buscando compatibilizar variadas demandas e contextos também fortemente diversificados". Enfim, os desafios que se apresentam são inúmeros, dada a dinamicidade do rio e da cidade aliada a questões de planejamento e as políticas públicas e institucionais (BAPTISTA, 2013).

O rio remete a uma memória vinculada à constituição física da cidade, que avança em um processo de urbanização econômico facilitado e auxiliado pelas águas do Caí. A cidade que avançava usufruía da via fluvial não só para benefícios econômicos, mas também contava com suas águas como importante referência para momentos de sociabilidade de seus moradores. As imagens apresentadas neste estudo formam um esboço imagético da riqueza e relevância do rio, pois mesclam diferentes personagens, apresentam-nos uma arquitetura imponente típica de um espaço físico de relevância econômica. Mas se o rio é a referência de desenvolvimento, a organização urbana em seu entorno nem sempre foi bem planejada, pois foi desconsiderada a força do curso das águas que ocasiona problemas para a cidade e os seus moradores, como as enchentes.

Não podemos deixar de mencionar que as cheias, como a do ano de 1992, por exemplo, castigaram a cidade, deixando as suas marcas em prédios seculares e atuais, além de atingir as familias que moram mais próximas ao seu curso, gerando dramas cotidianos e acionando estratégias de lidar com as oscilações das águas do Caí.

Conforme Bosi (1999, p. 53), "a lembrança é a sobrevivência do passado. O passado, conservando-se no espírito de cada ser humano, aflora à consciência na forma de imagens- 
lembrança" e, apesar dos problemas ocasionados pelas enchentes, podemos perceber, pela voz dos entrevistados, que os moradores de São Sebastião do Caí nutrem pelo seu rio um sentimento de agradecimento, bem como de respeito, pois ele possibilitou a construção de uma cidade, o desenvolvimento da região e serviu de referência para momentos de sociabilidade, entrelaçados no seu cotidiano. Essa percepção remete-nos, mais uma vez, a Bosi (1999, p. 419): "a força da evocação pode depender do grau de interação que envolve: eventos de repercussão restrita diferem, em sua memorização, dos que foram revividos por um grupo anos a fio".

Não há como pensar a cidade analisada sem levar em conta a presença marcante do rio. Em meio a uma dinamicidade que constituiu a história da localidade, as inter-relações entre a cidade e o seu rio apresentam-se em diferentes momentos, trazendo à tona momentos positivos e negativos, que permeiam as memórias e reconhecem-no como fundamental ou, em outras palavras, como o coração da cidade de São Sebastião do Caí.

\section{Referências}

ALVES FILHO. A. P; RIBEIRO, H. A Percepção do Caos Urbano, as Enchentes e as suas Repercussões nas Politicas Públicas da região Metropolitana de São Paulo. Saúde e Sociedade. v.15, n.3, p.145-161, set./ dez. 2006. https://doi.org/10.1590/S010412902006000300012

BAPTISTA, M; CARDOSO, A. Rios e cidades: uma longa e sinuosa história. Revista UFMG, Belo Horizonte, v. 20, n.2, p. 124-153, jul./ dez. 2013.

BARROS, J. D. Cidade e História. Petrópolis: Vozes, 2012.

BOSI, E. Memória e sociedade: lembranças de velhos. 7. ed. São Paulo: Companhia das Letras, 1999.

CAMPOS, E. C; FLORES, M. B. R. Carrosséis urbanos: da racionalidade moderna ao pluralismo temático (ou territorialidades contemporâneas). Revista Brasileira de História (ANPUH), São Paulo, v.27, n.53 p.267-296, jan-jun, 2007. https://doi.org/10.1590/ $\underline{\mathrm{S} 0102-01882007000100012}$

COSTA, A. J. S. T; CONCEIÇÃO, R. S; AMANTE, F. O. As enchentes urbanas e o crescimento da cidade do Rio de Janeiro: estudos em direção a uma cartografia das enchentes urbanas. Geo UERJ, Rio de Janeiro, n. 32, p.1-25, 2018

DE CERTEAU, M. A invenção do Cotidiano. 3. ed. Petrópolis: Vozes, 1998.
DEAN, W. A ferro e fogo: A história e a devastação da Mata Atlântica Brasileira. São Paulo: Cia. das Letras, 1996.

DUARTE, F. Rastros de um rio urbano- Cidade comunicada, cidade percebida. Ambiente e Sociedade, Campinas, v. 9, n. 2, jul./dez. 2006. https://doi. org/10.1590/S1414-753X2006000200006

DRUMMOND, J. A. A história ambiental: temas, fontes e linhas de pesquisa. Estudos Históricos, Rio de Janeiro, v. 4, n. 8, p. 177-197, 1991

ESPINNDOLA, M. A; NODARI, E. S. Relações complexas: as estiagens no Oeste de Santa Catarina. In: NODARI, E. S; CORREA, S. M. de S. (org.). Migrações e Natureza. São Leopoldo: OIKOS, 2013. p.165-184.

ESTEVES, N. Resgatando e divulgando a história de São Sebastião do Caí. 2002. (Sistematização de dados)

FREITAS, C. M.; XIMENES, E. F. Enchentes e saúde pública - uma questão na literatura científica recente das causas, consequências e respostas para prevenção e mitigação. Ciência \& Saúde Coletiva. Rio de Janeiro, v. 6, n.17, p.1601-1615, 2012. https://doi. org/10.1590/S1413-81232012000600023

GALLAS, Daniela Adels. Memória e identidade: a festa da bergamota em São Sebastião do Caí. Novo Hamburgo, 2014. 80 p. Monografia (Curso de História) -Universidade Feevale, Novo Hamburgo, 2014.

GLAESER, Mário. Disponivel em: http://historiasvalecai.blogspot.com/2011/07/1218-enchentes-cada-vez-maiores-e-mais.html. Acesso em: 04 mar. 2019

HISTÓRIAS DO VALE DO CAÍ. 30/01/2010. Disponivel em: http://historiasvalecai.blogspot.com. br/2010/01/795-as-medidas-da-barragem-rio-branco.html). Acesso em: 3 abr. 2019.

LIXO: OUTRO DRAMA QUE A ENCHENTE MOSTRA, Primeira Hora, p. 20, 23/07/2015.

MELLO, S. S. Na beira do rio tem uma cidade: urbanidade e valorização dos corpos d'água. 2008 348f. Tese (Doutorado em Arquitetura e Urbanismo) -- Faculdade de Arquitetura e Urbanismo, UNB. Brasilia, 2008. Disponivel em: http://repositorio.unb. $\mathrm{br} /$ bitstream/10482/1608/2/2008_SandraSoaresMello_cap_6_ate_final.pdf. Acesso em: 01 set. 2016.

MUDANÇAS CLIMÁTICAS. Disponivel em https://nacoesunidas.org/acao/mudanca-climatica/. Acesso em: 08 jul. 2019.

PÁDUA, J. A. As bases teóricas da história ambiental. Estudos Avançados, São Paulo, v. 24, n. 68 , p. 81-101, 2010. https://doi.org/10.1590/S010340142010000100009

PESAVENTO, S. J. Cidades visiveis, cidades sensiveis, cidades imaginárias. Revista Brasileira de História (ANPUH), São Paulo, v. 27, n. 53, p. 11-23, jan./ jun. 2007. https://doi.org/10.1590/S010201882007000100002

PESAVENTO, S. J. Espaço, sociedade e cultura: o cotidiano da cidade de Porto Alegre. In: BOEIRA, N; GOLIN, T. (org.). República Velha (1889-1930). Passo Fundo: Méritos, 2007. v. 3. t. 2, 2007. p.164-228. 
POLLAK, M. Memória, Esquecimento, Silêncio. Revista Estudos Históricos. Rio de Janeiro, v.2, n.3. p. 3-15, 1989.

POLLAK, M. Memória e identidade social. Revista Estudos Históricos Cpdoc/FGV, Rio de Janeiro, v. 5, n. 10, p. 200-212, 1992.

RAMINELLI, R. História Urbana. In: CARDOSO, C. F; VAINFAS, R. (org.). Domínios da História. Ensaios de Teoria e Metodologia. Rio de Janeiro: CAMPUS, 1997. p.185-202.

REINHEIMER, D. A navegação fluvial na República Velha Gaúcha. São Leopoldo: Oikos, 2010.

RIO CAÍ. Jornal NH, Novo Hamburgo, ano 1997, n. 957, p.11.

RÜCKERT, F. Q.; HARRES, M. M. Os banhados do rio dos Sinos e a História ambiental de São Leopoldo-RS. In: PEREIRA, E. M.; RÜCKERT, F. Q.; MACHADO, N. G. (org.). História Ambiental no Rio Grande do Sul. Lajeado: UNIVATES, 2014. p.17-38.

SAKAI, D. I. Santos; FROTA, J. A. D. Águas Urbanas: caminhos para um resgate. III Seminário Nacional sobre tratamento de áreas de preservação permanente em meio ambiente urbano e restrições ambientais ao parcelamento do solo. UFPA. Belém. 10 a 13 set. 2014. Disponivel em: http://anpur.org.br/ app-urbana-2014/anais/ARQUIVOS/GT1-162-3020140707141953.pdf. Acesso em: 12 ago. 2016.

SCHRÖDER, J. R. Cidade e o rio: representações e imaginários sobre São Sebastião do Caí. 2014. Disponivel em: http://biblioteca.feevale.br/Dissertacao/DissertacaoJaniceSchroder.pdf. Acesso em: 05 ago. 2014.

THOMPSON, P. A Voz do Passado. 2. ed. São Paulo: Paz e Terra, 1998.

THOMPSON, P. História oral e contemporaneidade. História Oral. Revista da Associação Brasileira de História Oral, São Paulo, n. 5, p. 9-28, jun. 2002.

WOLLMANN, C. A; SARTORI, M. da G. B. A percepção ambiental e climática da população de São Sebastião do Caí como forma de previsão de enchentes na bacia hidrográfica do rio Cai - Rio Grande do Sul. Revista Brasileira de Climatologia, Curitiba, v. 6, n. 6, p. 107-134, 2010. https://doi.org/10.5380/abclima.v6io.25590

WORSTER, D. Para fazer história ambiental. Estudos Históricos, Rio de Janeiro, v. 4, n. 8, p. 198-215, 1991.

\section{Magna Lima Magalhães}

Doutora em História pela Universidade do Vale do Rio do Sinos (Unisinos, Novo Hamburgo, RS, Brasil); professora do PPG Processos e Manifestações Culturais da Universidade Feevale, Novo Hamburgo, RS, Brasil.

\section{Claudia Schemes}

Doutora em História pela Pontificia Universidade Católica do Rio Grande do Sul (PUCRS, Porto Alegre, RS, Brasil); professora do PPG Processos e Manifestações Culturais da Universidade Feevale, Novo Hamburgo, RS, Brasil.

\section{Cleber Cristiano Prodanov}

Doutor em História pela Universidade de São Paulo (USP, São Paulo, SP, Brasil); professor do PPG Processos e Manifestações Culturais da Universidade Feevale, Novo Hamburgo, RS, Brasil.

\section{Endereço para correspondência}

Magna Lima Magalhães/Claudia Schemes/Cleber Cristiano Prodanov

ERS-239, 2755

93525-075

Novo Hamburgo, RS 